\author{
Medovar, L. ' , Stovpchenko, G. 1,2, Polishko, G. ${ }^{1}$, \\ Sybir, A. ${ }^{3}$, Kolomiets, D. ${ }^{1}$, and Kostetski, Yu. ${ }^{1}$ \\ ${ }^{1}$ Paton Electric Welding Institute of the NAS of Ukraine, \\ 11, Kazymyra Malevycha St., Kyiv, 03150, Ukraine, \\ +38044 20047 79, office@paton.kiev.ua \\ ${ }^{2}$ ELMET-ROLL Engineering Company, \\ P.O. Box 259, Kyiv, 03150, Ukraine, \\ +38 04433730 81, office@elmet-roll.com.ua \\ ${ }^{3}$ National Metallurgical Academy of Ukraine, \\ Gagarina Ave., 4, Dnipro, Ukraine, \\ $+38(056)$ 745-31-56, nmetau@nmetau.edu.ua
}

\title{
INNOVATIVE SOLUTIONS FOR MANUFACTURING HIGH-QUALITY RAILS IN UKRAINE
}

\begin{abstract}
Introduction. The development of railway transport is a necessary factor in the national development and European integration of Ukraine.

Problem Statement. Nowadays, over $80 \%$ of rail tracks in the national railways does not meet the requirements for bearing high-speed and heavy-load trains and needs to be replaced. At present, Ukrainian Railways corporation buys rails in foreign countries, which requires significant foreign exchange costs, and therefore the manufacture of high-quality mainstream and switch point rails in our country becomes an urgent need.
\end{abstract}

Purpose. To develop innovative options for organizing the production of premium rails in Ukraine.

Materials and Methods. Rail steel. Experimental melting and metallographic studies (using the optical and electron microscopy methods).

Results. A high homogeneity (high purity of boundaries and dispersion of primary grains, small inter-lamellar distance of perlite), enhanced properties of the rail metal ensured by conventional electroslag remelting (ESR), and similar characteristic of ingot steel produced by ESR in the current-supplying mold with twice as fast speed of formation have been experimentally proved. Experiments with high-speed ESR and test of fluoride slag in the mold on real continuous casting machine has created the technological framework for a hybrid process of continuous casting with electroslag heating of the meniscus in current-supplying mold (CC + ESR).

Conclusions. ESR enables reducing the minimum hump rate of casting, improving the density and uniformity of the metal in the axial zone, and maintaining a high quality of the ingot surface. Promising options of technological schemes of waste rail ESR for obtaining the ingots with cross section close to the rail profile have been developed and proposed. Using several modern ESR furnaces with special design will enable satisfying needs of Ukrainian Railways corporation in highquality main and switch point rails.

Keywords: railway, main rail, switch rail, rail steel, CC, ESR, hybrid process, and recycling of used rails.

Nowadays, in many countries, the development of transport infrastructure is a priority and a driving force for national economic development. In accordance with the ambitious goals of the Na-

(C) MEDOVAR, L., STOVPCHENKO, G., POLISHKO, G., SYBIR, A., KOLOMIETS, D., and KOSTETSKI, Yu., 2019 tional Transport Strategy Drive Ukraine 2030 for the period up to 2030 [1], the development of transport is mentioned among the key factors for Ukraine's national development and European integration. The strategy foresees the creation of conditions for the introduction of high-speed 
passenger rail transport (with a speed of up to $400 \mathrm{~km} / \mathrm{h}$ ), express delivery of valuable goods (with a speed of up to $350 \mathrm{~km} / \mathrm{h}$ ), fast delivery of containers (with a speed of, at least, $200 \mathrm{~km} / \mathrm{h}$ ), as well as connection of regional centers with a network of fast (with a speed from 160 to $200 \mathrm{~km} / \mathrm{h}$, by 2025) and high-speed (from 250 to $400 \mathrm{~km} / \mathrm{h}$, by 2030) railways, in particular, via public-private partnership (PPP) projects.

It is clear that all this requires the introduction of new sections of the railway track with high quality rails to ensure traffic safety. The economic approach to the implementation of the planned measures shall involve the maximum use of products of domestic manufacturers, which must match the best world models.

Production of premium quality rails requires upgrading the existing metallurgical facilities and creating new enterprises, technologies, and equipment based on innovative developments of the National Academy of Sciences and leading institutions with involvement of private enterprises in order to maximize the use of PPP benefits.

The basic approaches to a promising innovation project aiming at meeting the objectives of the Strategy are discussed below.

\section{RAILS PRODUCTION IN TODAY'S UKRAINE}

It is well-known that in countries with advanced network of railroads for high-speed passenger trains use only high quality rails with a length of more than $100 \mathrm{~m}$ in order to ensure proper alignment of rails and minimum amount of joints for improving interaction between the rolling stock and the rail track for smooth movement of trains $[2,3]$. Currently, in our country, more than $80 \%$ of the total number of rails constituting the railway tracks of Ukrzaliznytsia (Ukrainian railways) PJSC was manufactured at different times by Azovstal Steel Plant and referred to the first quality category [4]. Because of this, the need to improve the technical parameters of the rails is an urgent task. Meanwhile, PJSC Ukrzaliznytsia has to buy rails abroad, especially for the loaded sections. The organization of high-speed traffic re- quires increasing rails imports. The program of Metinvest Holding to that Azovstal Steel PJSC belongs, foresees the transition to the production of $50-100 \mathrm{~m}$ long high-quality rails, but it is associated with significant capital costs and time inputs for upgrade of the existing or installation of new equipment [5]. Today, rails are not among the manufacturer's priority, but they remain in the company's product portfolio. This is explained by both the market situation and, in our opinion and by some pending issues of the steelmaking technologies discussed in [6, 7].

In addition to solving the problem of producing high-quality main-line rails in Ukraine, it is also important to find efficient technologies for the manufacture of switch rails used for the production of switches. Most often, the switch rails are made by shaping the rail components or by milling, which requires significant time and material costs $[8,9]$.

Therefore, it is necessary to search for new approaches, among which the use of electroslag technologies for improving the rail steel quality may be a promising solution. The use of hybrid rail steel smelting/casting technology that combines the benefits of continuous casting and electroslag remelting opens up new opportunities for getting high-quality rail steel, including modern hypereutectic brands [10-13]. The new technical solutions proposed in [14] have enabled organizing the manufacture of the premium quality rails in Ukraine.

\section{HYBRID CONTINUOUS CASTING PROCESS WITH ELECTROSLAG HEATING OF THE MENISCUS (CC + ESR)}

One of the problems related to the rails quality is defects in the axial part of the workpiece caused by the liquation and shrinkage in the curing metal, which significantly reduce the service life of the rails. The defects appear as a result of insufficient stirring and feeding of the last portions of the liquid metal in the deep cup. A high flow rate of continuous casting (from $0.5 \mathrm{~m}$ to several meters per minute, depending on its cross section) 
Fig. 1. Microstructure of steel samples from model ESR ingots formed at different pulling rates: $1-20 \mathrm{~mm} /$ $\mathrm{min} ; 2-40 \mathrm{~mm} / \mathrm{min} ; a, c-$ view under optical microscope; $b, d-$ SEM (enlargement 100×)
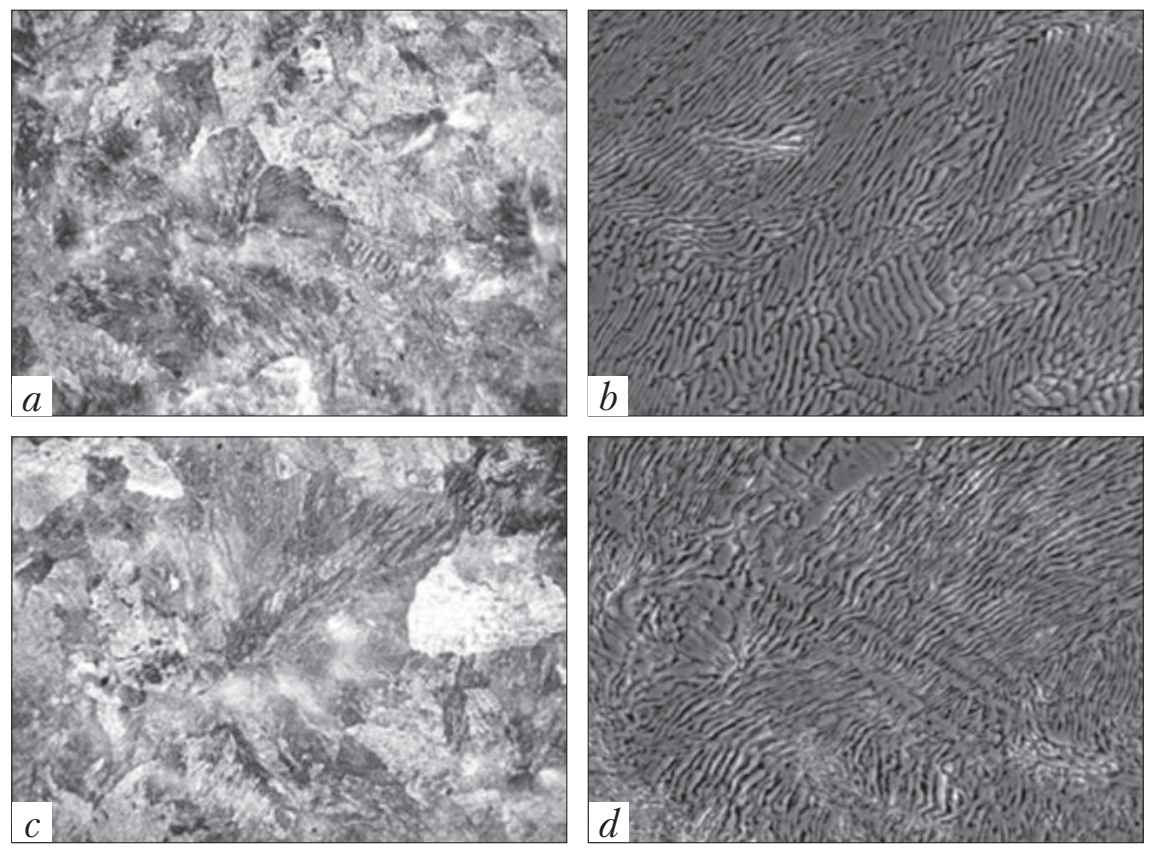

leads to the formation of a very deep liquid cup: even for a $200 \times 200 \mathrm{~mm}$ square ingot, the length of the liquid cup reaches up to $7 \mathrm{~m}$ at different withdrawal rates. Naturally, under such conditions, the stimulation of shrinkage of the continuous cast ingot in its axial part is limited and, as a result, liquation and porosity defects occur. However, it is impossible to significantly reduce the depth of the liquid cup, as the continuous casting machines have a certain lower limit of the casting speed, beyond which the meniscus freezes and the ingot surface becomes unsuitable for further rolling $[15,16]$.

Therefore, it has been proposed to use electroslag heating of the meniscus and the area of contact of the slag mix with the mold to reduce the specified threshold of the minimum casting rate and to prevent corrugation. This solution enables ensuring the surface quality of the continuous cast ingot, improving the density and homogeneity of the axial part by reducing the pouring rate and, accordingly, leads to reducing the depth of the two-phase zone and the depth of the liquid metal bath (metallurgical length of the continuously cast ingot).
The results of mathematical modeling of the formation of a round-shaped continuously cast ingot with a diameter of $500 \mathrm{~mm}$ of carbon steel at different casting rates $(200-500 \mathrm{~mm} / \mathrm{min}$ in $100 \mathrm{~mm} /$ min increments) have shown almost linear dependence of the depth of both the liquid metal bath and the two-phase zone on the casting rate [17]. The direct dependence of the metallurgical length of the liquid metal bath depth on the casting rate has been established to remain unchanged, even with the influence of the four secondary cooling zones taken into consideration (the lengths of the secondary cooling spray zones are assumed equal to $5000 \mathrm{~mm}$ (zone 1); $6000 \mathrm{~mm}$ (zone 2); $11000 \mathrm{~mm}$ (zone 3); and $11000 \mathrm{~mm}$ (zone 4) (the last two are consecutive sections of cooling, which differ in the intensity of water flow), which corresponds to the geometry of Continuous Casting Machine of PSJC Dzerzhinsky Dniprovsky Metallurgical Plant, Kamianske).

The estimated reduction of the two-phase zone depth from $29 \mathrm{~m}$ to $11 \mathrm{~m}$ (almost three times) as a result of slowing the rate of casting into a $500 \mathrm{~mm}$ diameter mold down to $300 \mathrm{~mm} / \mathrm{min}$ suggests that the proposed hybrid slag heating process [17] 
can give the second life to a semi-continuous casting of forging ingots with a large cross section on vertical machines [18]. A significant reduction in the fraction of liquid metal in the two-phase zone means that the proposed method for reducing the casting rate to prevent the formation of axial heterogeneity and shrinkage effects is quite promising.

The results of comparative study of the macrostructure and comprehensive evaluation of the microstructure of model ESR ingots obtained at different withdrawal rates (20 and $40 \mathrm{~mm} / \mathrm{min}$, respectively) gave reasons for similar conclusions.

In both ingots, there are traces of lamellar perlite and sections with globular perlite containing fragments of the cementite phase that underwent transformation into globular forms of cementite (Fig. 1). This is probably caused by uneven distribution of the elements and the duration of the metal stay in the temperature range of the pearlite transformation (from 650 to $550{ }^{\circ} \mathrm{C}$ ). In general, the microstructure of both ingots is homogeneous, dense, without any phase separation along the grain boundaries. The distance between the primary and the secondary axes of dendrites in the first and the second ingots slightly differs (Table 1).

It is known that the finer the structure of the steel, the more homogeneous it is, the better its properties in the cast state and, accordingly, in the final product. The distance between the primary and the secondary axes of the dendritic branches is a direct indication of the fineness of the primary dendritic structure.

A typical perlitic microstructure with thin cementite lamellae has been found in both ESR ingots. The quantitative evaluation of the interpla-

Table 1

The dimensions of structural components of ESR steel rail ingots with a diameter of $180 \mathrm{~mm}$

\begin{tabular}{|c|c|c|c|}
\hline $\begin{array}{c}\text { Ingot } \\
\text { withdrawal } \\
\text { rate } \\
(\mathrm{mm} / \mathrm{min})\end{array}$ & $\begin{array}{c}\text { Distance } \\
\text { between } \\
\text { the primary } \\
\text { axes, } \mu \mathrm{m}\end{array}$ & $\begin{array}{c}\text { Distance } \\
\text { between } \\
\text { the secondary } \\
\text { axes, } \mu \mathrm{m}\end{array}$ & $\begin{array}{c}\text { Interplanar } \\
\text { distance in perlite, } \\
\mu \mathrm{m}\end{array}$ \\
\hline 20 & 248 & 82 & 0.74 \\
40 & 162 & 43 & 0.56 \\
\hline
\end{tabular}

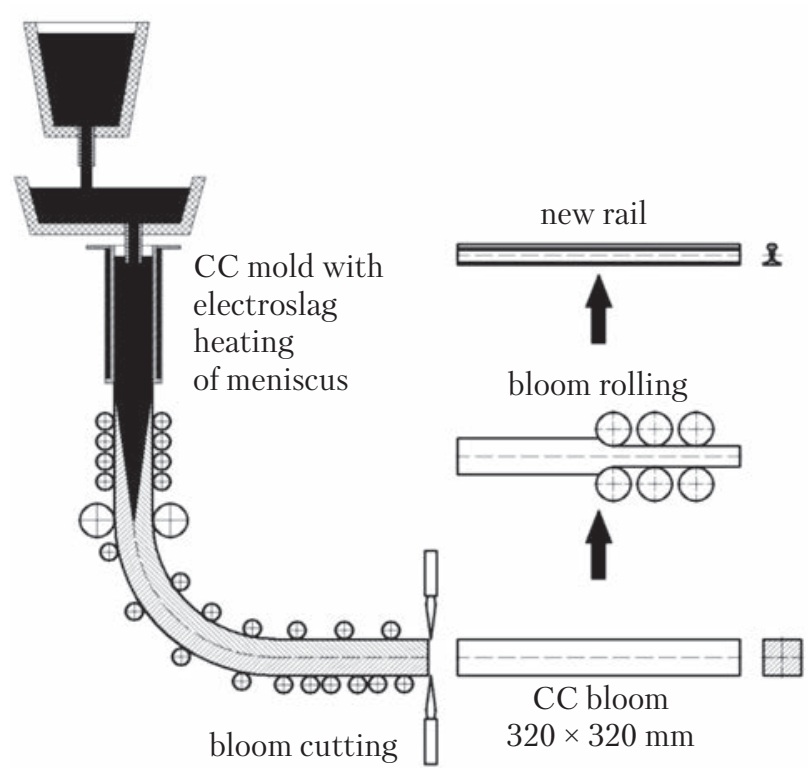

Fig. 2. Technological flowchart of the hybrid steel casting process by $\mathrm{CC}+\mathrm{ESR}$ plant

nar distance in the perlite has shown that the two ESR ingots of the K76F rail are almost identical (distance 0.54 and $0.76 \mu \mathrm{m}$, respectively). These values are higher as compared with the interplanar distance in the specimens of premium steel after deformation and heat treatment (the distance is about $0.2 \mu \mathrm{m}$ ), since the study was made using a cast metal without any deformation and heat treatment, which increase the perlite fineness.

The size of the pearlite grains in the ESR ingot with a withdrawal rate of $20 \mathrm{~mm} / \mathrm{min}$ is $100-$ $120 \mu \mathrm{m}$, the size of the subgrain is $20-30 \mu \mathrm{m}$, while that of the pearlite grains in the ingot obtained at a withdrawal rate of $40 \mathrm{~mm} / \mathrm{min}$ reaches $60-100 \mu \mathrm{m}$ and the subgrain size is $10-15 \mu \mathrm{m}$. That is, even a slight decrease in the metal feed rate while gradually molding the ingot has a positive effect on its structure. The density of the ingot metal increases by improving the shrinkage stimulation, which helps to eliminate the central heterogeneity of the ingot. The conclusions of mathematical modeling have been confirmed by the results of the study of ESR ingot metal obtained using current-supplying molds (Ø 110$620 \mathrm{~mm}$ ) in laboratory conditions of the Paton 
Electric Welding Institute of the NAS of Ukraine at different times [19-21].

In view of the above results, several original technical solutions for electro-slag remelting have been developed. They are practicable for rail production and fully consistent with the concept of a "circular economy" [22]. Today, all innovations are checked for patent clearance to be referred to the national priority.

The proposed technological line of the CC + ESR hybrid process is schematically shown in Fig. 2. The technical solutions underlying this technology have been tested on industrial CC casting machines at the stage of using ESR slag for steel casting and in laboratory conditions at the stage of electroslag heating for preventing the crystallization of the meniscus in the electroslag process with the use of liquid metal.

The key issue for the implementation of the $\mathrm{CC}+\mathrm{ESR}$ hybrid process can be the logistics sequence casting on a continuous casting machine, which usually have from two to six pulling lines (strands). The calculation for the existing CC of Azovstal Steel Casting Plant, where the average cast weight is $350 \mathrm{t}$, have shown that only one strand can be used for the hybrid process, since a significant decrease in the productivity makes impossible to complete casting the batch within a certain time. Given the need for the premium quality rails in Ukraine reaches about 10\% (10,00015,000 t) of Ukraine's total annual demand for main rails, the above process may be sufficient to satisfy it. When decreasing 5 times the operating speed of the machine, in order to provide adequate casting time, it is necessary either to reduce the amount of metal laddled from the arc furnace (AF), or to divide the cast into two parts with their successive feed to the ladle furnace (LF) and degassing, or to additionally heat the metal in the ladle or blasting pan while increasing the cross section of the casting ingot. The logistics of operations with the introduction of new CC + ESR casting technology will require accurate estimates and tuning-up, but the compatibility of the combination of different casting speeds on a mul-
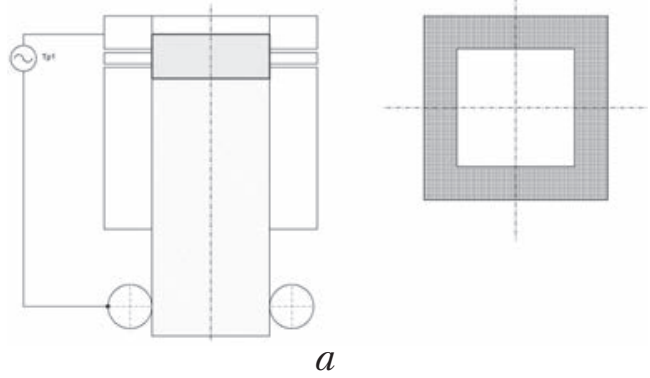

$a$
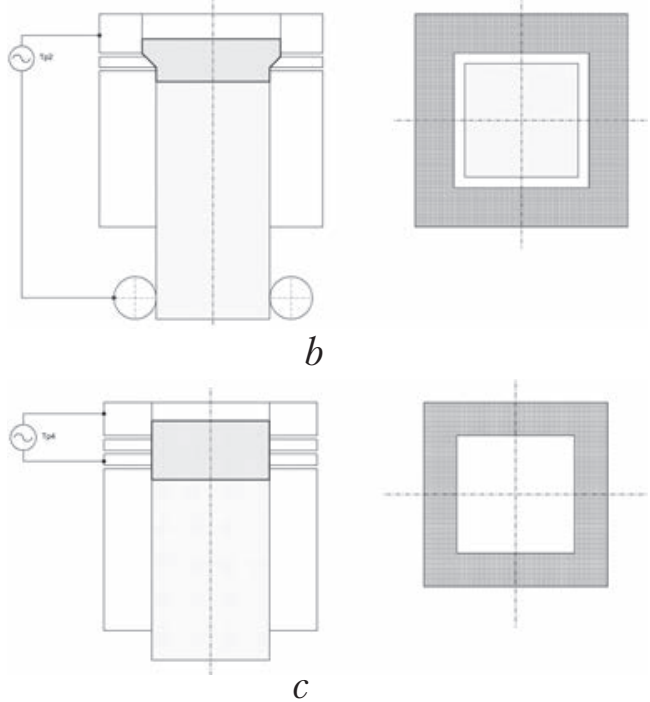

Fig. 3. Options for ESR process with current supply to pulling rollers of the machine using a current-supplying mold with a constant cross section $(a)$, with widening $(b)$, and with short circuit between the sections of current-supplying mold (c)

ti-strand continuous casting machine (CC) or a general decrease in its productivity are obvious.

Thus, the CC + ESR hybrid process can be implemented both on a single strand of the existing casting plant, on the entire operating $\mathrm{CC}$, and obviously, on a new plant that may be configured in several options.

To prevent the formation of surface defects at a reduced casting speed, the meniscus can be heated in a current-carrying mold with a constant cross section (Fig. 3, $a$ ) or with widening (Fig. 3, b) in the case of bottom current supply through the pulling roll facility, or using the scheme with a short circuit between the sections of the currentsupplying mold (Fig. 3,c). 
The last version of the electric circuit is the most promising in terms of simple implementation and minimal energy costs, but may be accompanied with an increased erosion of the copper mold, which can be avoided using other materials for the manufacture of the upper section. The efficiency of these materials in terms of service life and minimum contamination of cast metal requires full-scale testing on a pilot sample of the newly formed mold.

Naturally, for the introduction of the new CC + ESR technology in the industry, it is necessary to carry out all necessary qualification tests of the rails, in particular, fracture toughness (static and cyclic fracture toughness), fatigue characteristics, residual stress in the rail bottom, etc., in order to guarantee their high operational performance and economic efficiency.

\section{EFFICIENT \\ ELECTROSLAG RECYCLING OF WASTE RAILS}

The search for the possibility of producing the premium quality rails in Ukraine has led to the formulation of several more options for the efficient industrial implementation of electroslag technology, which are based on the current trends of the circular economy and the following key starting points:

+ Ukraine has both an urgent need to create and real opportunities to organize its own production of modern rails;

+ The key factor in improving the quality of rails in the modern technological cycle is the introduction of continuous casting process, and ESR is an effective method for heating the metal in the $\mathrm{CC}$ mold, which reduces the rate of casting/pulling the ingot and leads to a decrease in central heterogeneity;

+ There is a technical possibility of re-melting the rails removed from the tracks after the end of their service life;

+ For the production of modern rail steels by electroslag method it is necessary to realize casting in a dry box of electrodes with a low content of hydrogen (1 ppm) and oxygen (5$10 \mathrm{ppm}$ ) and to keep this level in ingots;

+ Despite the fact that once, because of a high cost of the ESR method, its practical application to the rails manufacture was suspended (in the 1990s, the comparative assessment based on the results of manufacturing a pilot batch of rails made of ESR metal showed that the cost of rails production of ESR metal and

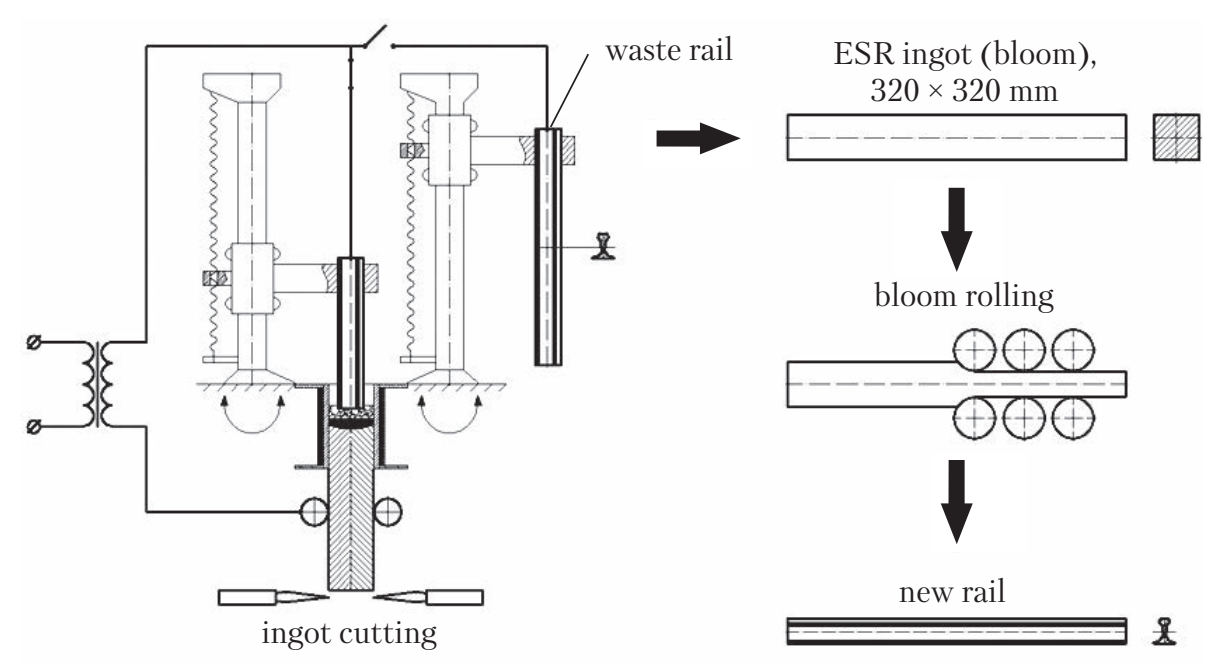

Fig. 4. ESR flowchart for modern ESR furnace with a dry box and the use of waste rails as consumable electrodes 


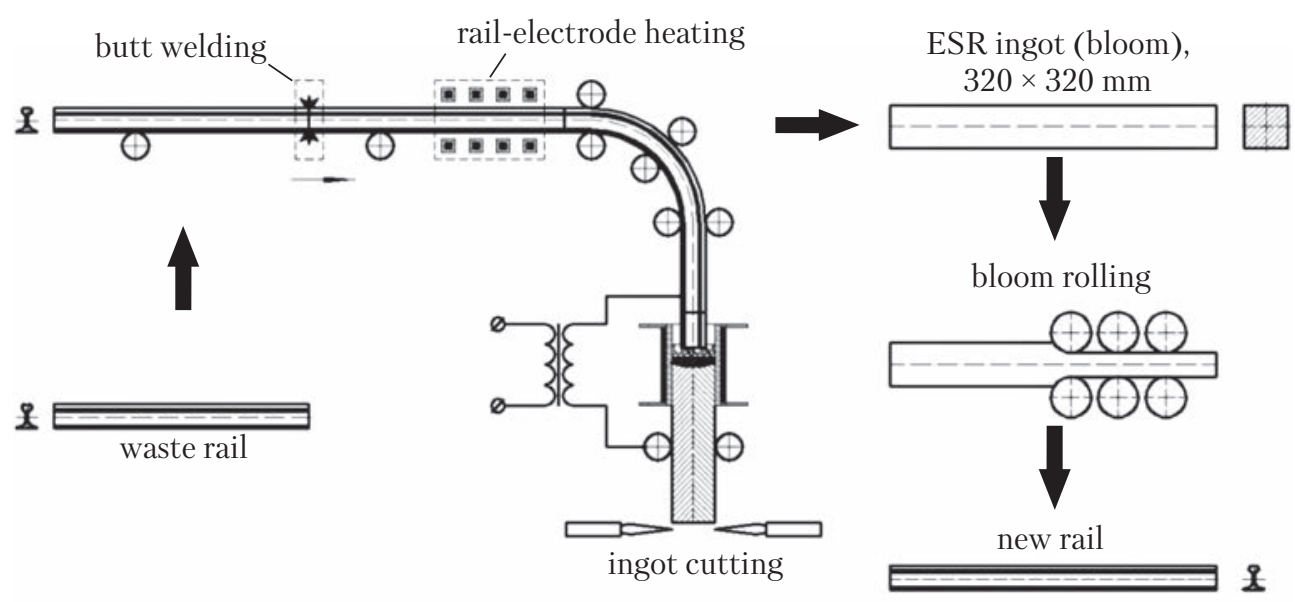

Fig. 5. Flowchart of SCC+ESR process for waste rails

that using the conventional technology amounted to RUB 332-339/t and RUB 160/t, respectively, in the prices of 1990). Today, based on the world experience, the cost of ESR rails is expected to increase by, at most, USD $0.2-$ 0.3 per $1 \mathrm{~kg}$ of rails (which is the largest indicator even for the conventional ingot molding rates in electroslag remelting of consumable electrodes), which justifies its application to the manufacture of premium quality rails.

It is clear that the use of current-supplying molds in the hybrid process and, in particular, in the ESR furnace for the recycling of waste rails, requires certain power input. The preliminary estimates of energy consumption for the ESR rail manufacture, as recommended in this research, (also for the combined process of casting $\mathrm{CC}+$ ESR rail steels), have showed that they do not exceed $400 \mathrm{kV} \bullet$ A for a mold with $320 \times 320 \mathrm{~mm}$ cross section. Thus, the remelting of waste rails using a modern ESR equipment, even according to a pessimistic forecast, reduces the cost of rails, as compared with the standard ESR technology, at least, by a third. However, using the state-ofthe-art technologies and equipment for casting, provided waste rails are used as consumable electrodes, the situation will be favorable for the proposed technical solutions, as the electrode cost usually accounts for about half of the rail cost.
In the course of research, several options of technological schemes for the manufacture of premium quality rails have been developed and proposed. This has enabled organizing the process of remelting waste rails to obtain a ingot for new ones, the dimensions of which either correspond to the size of the $\mathrm{CC}$ ingot used for rolling the rails, or are as close as possible to the rail profile, in order to reduce the reshaping costs.

The first option of the organization of the process is shown in Fig. 4.

In Ukraine, there are currently no ESR furnaces of a modern design, with a dry box and replaceable electrodes, which, on the one hand, complicates the implementation of the proposed method for remelting of rails, and on the other hand, gives an opportunity to offer a specialized design of the ESR furnace with additional equipment that enables transforming the remelting process into a semi-continous one. The concept of a specialized ESR furnace for melting waste rails foresees that the waste rails are continuously fed to the mold, in particular, the current-supplying one (Fig. 5), via a horizontal induction heating device, with their subsequent bending through 90 grad.

Remelting waste rails into new ones in a dry box is not accompanied with significant losses of alloying elements, iron, etc., and slag metal treat- 


\begin{tabular}{|c|c|c|c|}
\hline \multicolumn{4}{|c|}{$\begin{array}{l}\text { Indicative Dimensions and Weights } \\
\text { of Waste Rails to be Used in the ESR Process }\end{array}$} \\
\hline \multirow{2}{*}{ Characteristics } & \multicolumn{3}{|c|}{ Dimensions of ESR ingot, $\mathrm{mm} \times \mathrm{mm}$} \\
\hline & $320 \times 320$ & $400 \times 400$ & $400 \times 500$ \\
\hline Weight of $1 \mathrm{~m}$ ingot $\mathrm{t}$ & 0.8 & 1.25 & 1.57 \\
\hline $\mathrm{ESR}$ rate, $\mathrm{kg} / \mathrm{h}$ & 600 & 1000 & 1500 \\
\hline $\begin{array}{l}\text { ESR linear pulling ra- } \\
\text { te, } \mathrm{m} / \mathrm{h}\end{array}$ & $0.6-0.85$ & $0.75-0.90$ & $0.90-1.05$ \\
\hline $\begin{array}{l}\text { Linear rate of feed of } \\
\text { rails for remelting, } \mathrm{m} / \mathrm{h}\end{array}$ & $8-10$ & $13-15$ & $20-25$ \\
\hline
\end{tabular}

ment ensures the purity of steel and a favorable morphology of non-metallic inclusions.

Indicative weights, lengths and P65 rails feed rates (a $100 \mathrm{~m}$ rail has a weight of $6.5 \mathrm{t}$ ) to be remelt, as well as the pulling rate of ESR ingots of various sizes are given in Table 2.

Given numerous discussions with Ukrzaliznytsia specialists, as already mentioned, in recent years the country's need for the premium quality rails has reached about $10,000-15,000$ tonnes annually or about $70-110 \mathrm{~km}$ tracks of $\mathrm{P} 65$ rails. Such a quantity of ESR metal can be produced by 4-6 modern specialized plants, in a dry box, and, at least, doubled melting speed without reducing the steel quality will contribute to the formation of price competitiveness of these products. It would be advisable to build such a micro-plant as a part of PJSC Ukrzaliznytsia that removes used main rails from the railway tracks, or at a metallurgical plant that has a rolling mill for manufacturing rails. Unfortunately, today, all existing rolling mills that can manufacture rails in Ukraine have been outdated and require major upgrade or replacement.

The most effective use of the proposed method can be the production of switch rails from ingots having a cross section that is as close as possible to the required size. When recycling waste rails, the ESR metal structure has a high density and quality, which ensures exceptional properties of switch rails at a low cost. The use of electroslag technology for the production of switch rails can significantly reduce the cost of machining and increase the service life of the critical units of the railroad bed due to a high quality of the ESR metal.

Schemes with the use of a current-supplying mold have been developed for practical application of the CC + ESR hybrid process. The mentioned process can significantly reduce the ingot pulling rate by heating the meniscus and improve the density and uniformity of the ingot metal while guaranteeing the quality of its surface.

The metallographic studies of ESR metal of various brands have shown that due to a higher purity of grain boundaries, there are no grainboundary precipitation of impurities, which provides enhanced metal properties, in particular, plasticity.

New promising schemes for the production of new rails by the ESR method at a specialized micro-plant (conditionally, a micro-plant within Ukrzaliznytsia) have been proposed. Using several modern ESR furnaces of special configuration, they enable remelting waste rails for manufacturing premium quality main/switch rails, with a minimum consumption of dopes and alloying agents.

\section{REFERENCES}

1. About the praise of the National Transport Strategy of Ukraine for the period until 2030. URL: https://www.kmu. gov.ua/ua/npas/pro-shvalennya-nacionalnoyi-transportnoyi-strategiyi-ukrayini-na-period-do-2030-roku (Last accessed: 13.06.2018).

2. Sirong Yi. Dynamic Analysis of High-Speed Railway Alignment: Theory and Practice. URL: https://www.sciencedirect.com/science/book/9780128128879 (Last accessed: 15.06.2018).

3. Rail market: Russian products crowd out imports. URL: http://www.indexbox.ru/news/rossijskie-relsy-vytesnyayutimport/2016: Index box (Last accessed: 15.06.2018).

4. "Ukrzaliznytsia" passes to the rails of the highest category, which are made by "Azovstal". URL: http://mrpl.city/ news/view/ukrzaliznytsya-perehodit-na-relsy-vysshej-kategorii-kotorye-izgotovleny-azovstalyu (Last accessed: 31.07.2018). 
5. AZOVSTAL plans to master the production of a new type of rail. URL: https://azovstal.metinvestholding.com/ru/ press/news/show/2589 (Last accessed: 31.07.2018).

6. Medovar, L. B., Stovpchenko, G. P., Polishko, G. O., Pedchenko, E. A., Zaitsev, V. A. (2018). Modern rail steels and solutions ESR (Review). Information 1. Operating conditions and defects observed. Sovremennaya electrometallurgiya, 1, 3-7. https://doi.org/10.15407/sem2018.01.01 [in Ukrainian].

7. Medovar, L. B., Stovpchenko, A. P., Polishko, A. A., Kolomiets, D. A., Pedchenko, E. A., Zaitsev, V. A. (2018). Modern rail steels. application of ESR (Review). Information 2. Requirements of standards to chemical composition of steels for railway rails of main-line tracks. Sovremennaya electrometallurgiya, 2, 28-36. https://doi.org/10.15407/sem2018.02.03 [in Ukrainian].

8. GOST R 55820-2013 Switch and crossing rails. Specifications.

9. Maksymov, A. B., Gofman, L.,D., Kibalov, A. A. (2008). Quality management system for switch rails. Innovative Materials and Technologies in Metallurgy and Mechanical Engineering, 1, 125-128 [in Russian].

10. Ordóñez Olivares, R., Garcia, C. I., Robles Henrández, F. C. (2013). Metallurgy of high-carbon steels for railroad applications. J. S. Afr. Inst. Min. Metall., 113(2), 155-162. URL: http://www.scielo.org.za/scielo.php?script=sci_arttext\&pid=S2225-62532013000200016\&lng=en\&nrm=iso Accessed on: 31 July 2018.

11. Girsch, G., Jörg, A., Schoech, W. Managing rail life to match performance and cut costs. Railway Gazette International, 2010 (August), 45-48. URL: https://www.speno.ch/images/speno-docs/english/RGIN-1008-rail\%20steels\%20articlehi\%20res.pdf Accessed on: 31 July 2018.

12. Ordonez, R., Garcia, C. I., Deardo, A., Kalay, S. (2009). New rail steels for the $21^{\text {st }}$ century. Materials Science and Technology Conference and Exhibition 2009, MS and T'09. V. 3. 1614-1624.

13. Pointner, P. (2008). High strength rail steels. The importance of material properties in contact mechanics problems. Wear, 265 (9-10), 1373-1379.

14. Kuchuk-Yatsenko, S. I., Didkovsky, A. V., Shvets, V. I., Rudenko, P. M., Antipin, E. V. (2016). Flash-butt welding of highstrength rails of nowadays production. Avtomaticheskaya svarka, 5-6, 7-16. https://doi.org/10.15407/as2016.06.01 [in Russian].

15. Lee, G.-G., Thomas, B. G., Kim, S.-H., Shin, H.-J., Baek, S.-K., Choi, C.-H., Kim, D.-S., Yu, S.-J. (2007). Microstructure Near Corners of Continuous-Cast Steel Slabs Showing Three-Dimensional Frozen Meniscus at Hooks. Acta Materialia, 55 (20), 6705-6712.

16. Lee, G.-G., Shin, H.-J., Thomas, B. G., Kim, S.-H., Kim, D.-S., Yu, S.-J. (2007). Three-dimensional Microstructure of Frozen Meniscus and Hook in Continuous-cast Ultra-low-carbon Steel Slabs. AISTech 2007, Steelmaking Conference Proc., (May 7-10, 2007, Indianapolis, IN), AIST, Warrendale, PA., v. 1, 1-10.

17. Medovar, L. B., Stovpchenko, A. P., Sibir, A. V., Volchenkov, Ye. A., Pedchenko, E. A., Polishko, A. A., Lebed, V. A. (2017). Modeling of continuous casting by combined process of MCCB + ESR. Sovremennaya electrometallurgiya, 4, 3-7. https://doi.org/10.15407/sem2017.04.01 [in Russian].

18. JUMBO BLOOM VERTICAL CASTER. URL: http://www.timkensteel.com/what-we-make/high-performancesteel/jumbo-bloom-vertical-caster (Last accessed: 31.07.2018).

19. Medovar, L. B., Tsykulenko, A. K., Fedorovskii, B. B., Shevchenko, N. T., Latsman, I. A., Grabovskiy, Ts. F., Petrenko, V. L. (2000). About formation of the surface of nickel superalloy ingots during ESR in a current conductive mold. Problemy SEM, 4, 7-14 [in Russian].

20. Medovar, L. B., Saenko, V. Ya., Stovpchenko, A. P., Tsykulenko, A. K., Shevchenko, N. T., Zhuravel, V. M., Polishko, A. A., ..., Lebed, V. A. (2010). Electroslag technology of production of large forging ingots. Sovremennaya electrometallurgiya, 3, 5-10 [in Russian].

21. Polishko, A. A. (2012). Enlarging ingots by successive circumferential electroslag surfacing. Sovremennaya electrometallurgiya, 2 (107), 14-16 [in Russian].

22. Korhonena, Jouni, Honkasalob, Antero, Seppäläc, Jyri. (2018). Circular Economy: The Concept and its Limitations. Ecological Economics, 143, 37-46.

Received 20.02.19

Revised 21.04.19

Accepted 24.06.19 


\author{
Л.Б. Медовар ${ }^{1}$, Г.П. Стовпченко ${ }^{1,2}$, Г.О. Полішко ${ }^{1}$, \\ А.В. Сибір ${ }^{3}$, Д.В. Коломієи ${ }^{1}$, Ю.В. Костеикий ${ }^{1}$ \\ ${ }^{1}$ Інститут електрозварювання ім. С.О Патона НАН України, \\ вул. Казимира Малевича, 11, Київ, 03150, Україна, \\ +38(044) 200-47-79, office@paton.kiev.ua \\ ${ }^{2}$ Інжинірингова компанія «ЕЛМЕТ-РОЛ», \\ а/с 259, Київ, 03150, Україна, \\ +38(044) 337-30-81, office@elmet-roll.com.ua \\ ${ }^{3}$ Національна металургійна академія України, \\ пр. Гагарина, 4, м. Дніпро, 49600, Україна, \\ +38 0567453156 , nmetau@nmetau.edu.ua

\section{ІННОВАЦІЙНІ РІШЕННЯ ПРОБЛЕМИ ОРГАНІЗАЦІЇ ВИРОБНИЦТВА РЕЙОК НАЙВИЩОГО ГАТУНКУ В УКРАЇНІ}

Вступ. Розвиток залізничного транспорту є необхідним чинником національного розвитку та європейської інтеграції України.

Проблематика. Станом на сьогодні понад 80 \% рейок в коліях вітчизняної залізниці не відповідають вимогам швидкісного руху та пропуску великовагових поїздів і потребують заміни. Наразі ПАТ «Укрзалізниця» купує рейки за кордоном, що потребує суттєвих валютних затрат, а тому налагодження в країні виробництва високоякісних магістральних та вістрякових рейок стає нагальною необхідністю.

Мета. Розробка інноваційних варіантів організації виробництва рейок преміум класу в Україні.

Матеріали й методи. Рейкова сталь. Експериментальні плавки і металографічні дослідження (оптична та електронна мікроскопія).

Результати. Експериментально доведено високу однорідність (високу чистоту границь та дисперсність первинних зерен, малу міжламельну відстань перліту) та підвищений рівень властивостей рейкового металу, який виготовлено традиційним електрошлаковим переплавленням (ЕШП), та аналогічні показники металу зі зливків, вироблених ЕШП в струмопідвідному кристалізаторі з вдвічі вищою швидкістю формування. Експериментами зі швидкісним ЕШП та випробуванням фторидного шлаку в кристалізаторі реальної машини безперервного лиття заготовок (МБЛЗ) створено технологічне підгрунтя гібридного процесу безперервного литва з електрошлаковим підігрівом меніску струмопідвідним кристалізатором (БЛ+ЕШП).

Висновки. ЕШП дозволяє зменшити мінімальну порогову швидкість розливу на МБЛЗ, покращити щільність та однорідність металу осьової зони й зберегти високу якість поверхні заготівки. Розроблені й запропоновані перспективні варіанти технологічних схем електрошлакового переплавленняу відпрацьованих рейок з одержанням заготовок з перетином, наближеним до профілю рейки, з використанням декількох сучасних печей ЕШП спеціальної конструкції забезпечать потребу ПАТ «Укрзалізниця» в магістральних та/або вістрякових рейках преміум якості.

Ключові слова: залізничні магістральні рейки, вістрякові рейки, рейкові сталі, МБЛЗ, ЕШП, гібридний процес, переробка відпрацьованих рейок. 


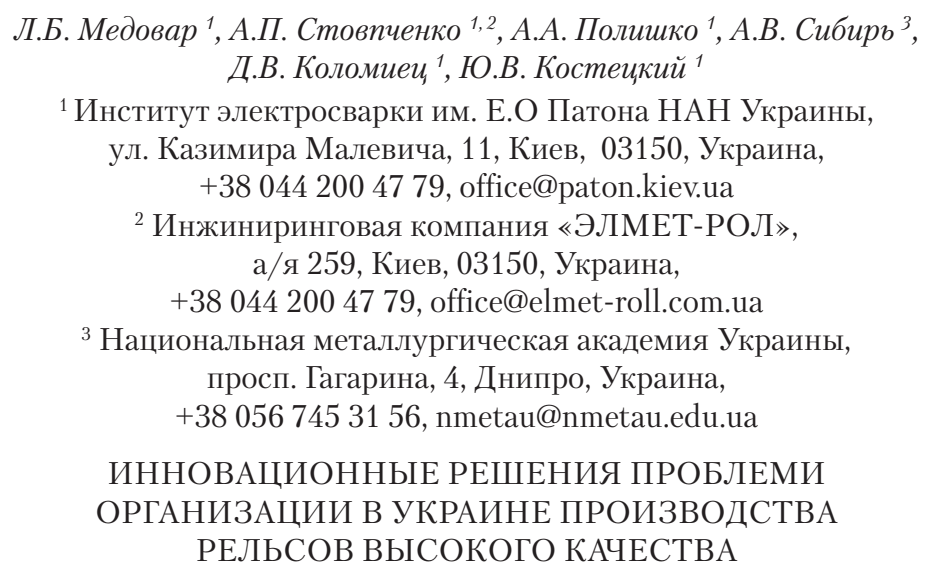

Вступление. Развитие железнодорожного транспорта является необходимым фактором национального развития и европейской интеграции Украины.

Проблематика. На сегодня более 80 \% рельсов в путях отечественной железной дороги не соответствуют требованиям скоростного движения и пропуска тяжеловесных поездов и требуют замены. Сейчас ОАО «Укрзализныця» покупает рельсы за рубежом, что требует существенных валютных затрат, а поэтому налаживание в стране производства высококачественных магистральных и остряковых рельсов становится насущной необходимостью.

Цель. Разработка инновационных вариантов организации производства рельсов премиум класса в Украине.

Материалы и методы. Рельсовая сталь. Экспериментальные плавки и металлографические исследования (оптическая и электронная микроскопия).

Результаты. Экспериментально доказана высокая однородность (высокую чистоту границ и дисперсность первичных зерен, малое межламельное расстояние в перлите) и повышенный уровень свойств рельсового металла, изготовленного традиционным электрошлаковым переплавом (ЭШП), и аналогичные показатели металла из слитков, произведенных путем ЭШП в токоподводящем кристаллизаторе с вдвое более высокой скоростью формирования. Экспериментами со скоростным ЭШП и испытанием фторидного шлака в кристаллизаторе реальной машины непрерывного литья заготовок (МНЛЗ) создана технологическая основа гибридного процесса непрерывного литья с электрошлаковым подогревом мениска токоподводящим кристаллизатором (НЛ + ЭШП).

Выводы. ЭШП позволяет уменьшить минимальную пороговую скорость разливки на МНлЗ, улучшить плотность и однородность металла осевой зоны и сохранить высокое качество поверхности заготовки. Разработаные и предложеные перспективные варианты технологических схем электрошлакового переплава отработанных рельсов с получением заготовок сечением, приближенным к профилю рельса, с использованием нескольких современных печей ЭШП специальной конструкции позволят обеспечить потребность ОАО «Укрзализныця» в магистральных и/ или остряковых рельсах премиум качества.

Ключевые слова: железнодорожные магистральные рельсы, остряки рельсы, рельсовые стали, МНЛЗ, ЭШП, гибридный процесс, переработка отработанных рельсов. 